\title{
The application of salivary gland scintigraphy in quantitative analysis of xerostomia as a frequent salivary gland dysfunction: a review article
}

\author{
Hanieh Kaviani and Mina Khayamzadeh*
}

\author{
Department of Oral and Maxillofacial Radiology, Faculty of Dentistry, Tehran University of Medical Sciences, International Campus, Tehran, Iran. \\ Correspondence to Mina Khayamzadeh (email: mkhayamzadeh@yahoo.com). \\ (Submitted: 14 March 2019 - Revised version received: 11 April 2019 - Accepted: 29 May 2019 - Published online: 26 August 2019)
}

\begin{abstract}
Salivary gland scintigraphy (SGS) that is known as the most frequent non-invasive imaging test could be used for distinguishing dysfunction of salivary gland in patients who suffer from Sjögren's syndrome or/and in patients with thyroid cancer after applying radioactive iodine therapy. One of the main side effects of salivary gland scintigraphy (SGS) in patients with differentiated thyroid cancer, and also radiation therapy in patients who suffer from neck and head cancers is oral dryness that is called xerostomia. Anyway, comprehensive futuristic information around conversions in function of salivary gland after SGS are rare. Accordingly, the initial purpose of this study was to distinguish the side effects of SGS on motivated flow rate of oral saliva. As a result, patients after being treated may experience correlated syndromes like xerostomia that could cause oral dryness, sore throat, dental decay, variation in voice quality, bad functions of swallowing and chewing and also altered taste. In this comprehensive study, the author tried to review the published studies characterizing SGS technique in patients who suffer from xerostomia and also aimed to discuss around progresses made in the treatment of this disorder. Additionally, for determining the ability of undertaking salivary gland scintigraphy for evaluation of salivary gland health in patients who suffer from xerostomia disorder, some new methods should be developed.

Keywords salivary glands, xerostomia, salivary gland dysfunction, review
\end{abstract}

\section{Introduction}

The decrement of salvia flow could cause the dryness of mouth that also called xerostomia. As mentioned by various researcher's xerostomia might be a symptom of different medical situations, a secondary effect of applying different kind of remedies or may also be a side effect of neck or/and head radiation. Additionally, as cited by them, it is not a dangerous disease. On the other hand, it might be associated with reduced function of salivary gland. However, radiation could influence the quality and quantity of saliva produced and could reduce the $\mathrm{pH}$ and also increase the viscosity. ${ }^{1}$ Patients who suffer from xerostomia would experience some clinical incidence of difficulty in speaking, chewing and swallowing somehow this disorders could be occured with burning Mouth Syndrome (BMS) prevalence, altered taste, halitosis, dryness in the mouth, inflammation of the tongue, peeled and cracked lips, oral thrush and tooth decay despite adequate health care of the mouth mucosa (Table 1). ${ }^{2-4}$ So, xerostomia could decrease the life quality of patients who are affected with this disorder.

\section{Xerostomia Causing Factors}

The fundamental xerostomia etiology could be divided into two categories that are mentioned in Table 2: local factors and systemic disorders. Systemic disorders that could cause xerostomia are such as infectious, autoimmune diseases and granuloma inflammation. On the other hand, local factors that could cause xerostomia are such as radiation therapy of neck and head, some drugs and also various factors that affect lifestyle.

On the other hand, xerostomia could cause tooth decay, the mandible osteoradionecrosis and also ulceration of soft tissue. ${ }^{5,6}$ Anyway, it could be seen that the xerostomia intensity is related to the applied radiotherapy dose and also the volume and size of gland irradiation. Newly oral pilocarpine that are known as cholinergic agonists has been widely applied in post-radiation xerostomia treatment. ${ }^{2,7,8}$ It is a cholinomimetic drug which acts mainly as a muscarinic with beta adrenergic agonists activity. It also motivates exocrine glands, sweating, lacrimation and on the other hand could increase secretions of stomach and pancreas. ${ }^{9}$ The effectiveness of this remedy has been shown in various trials somehow about half of the patients signified satisfactory responses. ${ }^{2,7,8}$

Radiotherapy as well as chemotherapy and surgery are the initial modalities in treatment of neck and head cancers. In spite of radiotherapy that could affect tumors, ionizing irradiation may damage the normal tissues that is placed in the radiation side. Radiation by causing morphological and functional changes in oral mucosa and salivary glands could create xerostomia disorder. ${ }^{1}$ Xerostomia in general is recognized as the subjective sense of unsatisfactory of oral dryness, which is associated with objective experiences of dysfunction of salivary gland. Caglar et al. ${ }^{10}$ by working on scintigraphic evaluation of salivary gland dysfunction in patients with thyroid cancer after radioiodine treatment reported that oral mucosa dryness could be known as a symptom systemic disorder like Sjögren's syndrome, a secondary effect of anticholinergic agent, antiadrenergic agents that prevent the sympathetic nervous system activity, cytotoxic chemotherapy or/and it could be created as a side effect of neck and head region radiation therapy. Radioiodine therapy is a helpful treatment that accomplished under salivary gland motivation to increase salivary gland function. Anyway, under a condition when salivary gland motivated, damages of parenchyma could be seen after radioiodine therapy by using of quantitative salivary 
gland scintigraphy. The dysfunction of salivary gland is one of the most frequent advents of Sjogren's syndrome (SS) patients that often occur after radioactive iodine (RAI) therapy. SS is a persistent disease of immune system specified by lymphoid influence of salivary glands which could cause dryness of mouth mucosa. ${ }^{11,12}$ On the other hand, the dysfunction of salivary gland is one of the main difficulties of RAI therapy in patients with thyroid cancer whose tumor is well-differentiated. According to Solans et al. ${ }^{13}$ researches around salivary and lacrimal gland dysfunction it could be seen that about $30-50 \%$ of patients who suffer from thyroid cancer and have treated with RAI therapy may experience xerostomia syndrome after a long period of time. As cited by Nishiyama et al. ${ }^{14}$ Tc- $99 \mathrm{~m}$ pertechnetate as one of the main technetium radiopharmaceuticals being applied in thyroid imaging and salivary gland scintigraphy (SGS) for evaluating dysfunction of salivary gland in patients who are affected with SS disorder. On the other hand, at a similar study by Caglar et al. ${ }^{10}$ have studied scintigraphic evaluation of salivary gland dysfunction in patients with

\section{Table 1 Xerostomia clinical appearances}

\begin{tabular}{ll}
\hline $\begin{array}{l}\text { Appeared functional } \\
\text { problems }\end{array}$ & $\begin{array}{l}\text { Consequences of morphologic } \\
\text { findings }\end{array}$ \\
\hline $\begin{array}{l}\text { Swallowing problems } \\
\text { Chewing problems }\end{array}$ & $\begin{array}{l}\text { Burning mouth syndrome } \\
\text { Halitosis } \\
\text { Dry buccal mucosa inflammation of } \\
\text { the tongue } \\
\text { Cracked and peeled lips }\end{array}$ \\
& $\begin{array}{l}\text { Oral candidiasis } \\
\text { Speaking problems }\end{array}$ \\
Taste changes & Tooth caries \\
\hline
\end{tabular}

thyroid cancer and reported that Tc-99m pertechnetate is widely used after RAI therapy in patients with thyroid cancer. Additionally, they mentioned that, there in no any comparison between the SGS exploration in patients with thyroid cancer and SS patients after RAI.

\section{Etiology of Xerostomia}

Xerostomia that caused from radiation and known as oral mucosa dryness is a frequent complaint from patients who are treated for neck and head malignant tumor. The fundamental etiology of xerostomia contains a diversity of systemic disorders and some other positional factors. Xerostomia has many negative concepts such as decreasing the quality of life, a lot of oral complications and pain like, altered taste, sore throat, tooth decay, voice quality changes, disability of swallowing and chewing function. ${ }^{1,2,5,6,8}$ For the reason that the risk of xerostomia caused by radiation depends on the anticancer remedy type and irradiation dose delivered to the tissue of gland, xerostomia could be considered to be dependent on various factors. ${ }^{7}$ After the first week of applying radiotherapy, the flow rate of saliva could decrease rapidly and then progressively decrease more and more with increasing radiation dose under $10 \%$ of its baseline border..$^{15}$ By referencing the literature, when the irradiation dose increases up to $40 \mathrm{~Gy}$, a considerable decrease in the flow rate of saliva would occur. ${ }^{16,17}$

In spite of the fact that the prevalence of xerostomia prevalent in about $90 \%$ of patients, management and inhibition of salivary dysfunction caused via radiation are critical challenging matters. As reported by some previous researches, none of remedial and preventive agents that have been suggested did not furnished adequate satisfactory outcomes. Some of these agents are: cholinergic stimulants, oral mucosal

\begin{tabular}{|c|c|c|c|}
\hline \multicolumn{2}{|l|}{ Systemic factors } & \multicolumn{2}{|l|}{ Local factors } \\
\hline \multirow[t]{2}{*}{ Endocrinologic causes } & - Diabetes mellitus (DM) & Head and neck radiation & N.A \\
\hline & - Autoimmune diseases of thyroid & & \\
\hline Autoimmune causes & $\begin{array}{l}\text { - Syndrome of Sjögren } \\
\text { - Rheumatoid arthritis } \\
\text { - Systemic lupus erythematosus } \\
\text { - Scleroderma } \\
\text { - Initial cirrhosis of bile }\end{array}$ & Lifestyle factors & $\begin{array}{l}\text { - Tobacco use } \\
\text { - Alcohol use } \\
\text { - Dehydration } \\
\text { - Heavy snoring } \\
\text { - Mouth breathing } \\
\text { - Upper respiratory tract infections }\end{array}$ \\
\hline Infectious causes & $\begin{array}{l}\text { - Actinomycosis } \\
\text { - Human immunodeficiency virus } \\
\text { - Hepatitis C virus } \\
\text { - Human T-lymphotropic } \\
\text { virus type } 1 \text { virus } \\
\text { - Cytomegalovirus } \\
\text { - Epstein- Barr virus }\end{array}$ & $\begin{array}{l}\text { Most frequent categories } \\
\text { of drugs }\end{array}$ & $\begin{array}{l}\text { - Anticholinergic drugs } \\
\text { - Antiparkinsonian drugs } \\
\text { - Antidepressants drugs } \\
\text { - Antipsychotics drugs } \\
\text { - Antihistamines drugs } \\
\text { - Antihypertensives drugs } \\
\text { - Sedative agents } \\
\text { - Anti- HIV drugs } \\
\text { - Cytotoxic drugs }\end{array}$ \\
\hline Granulomatous causes & $\begin{array}{l}\text { - Tuberculosis } \\
\text { - Sarcoidosis }\end{array}$ & & - Antineoplastic drugs \\
\hline Other systemic causes & $\begin{array}{l}\text { - End-stage disease of kidneys } \\
\text { - Hemochromatosis } \\
\text { - Amyloidosis } \\
\text { - Parkinson disorder } \\
\text { - Ectodermal dysplasia } \\
\text { - The process of aging }\end{array}$ & & - Opioids \\
\hline
\end{tabular}


lubricant formulas, hyperbaric oxygen, vitamin C/E complex supplementation, chewing gums, mesenchymal stem cell, salivary stimulants, salivary substitutes. ${ }^{18-24}$ The strategical results of fundamental trials that examine different pharmacological and non-pharmacological remedy methods for the administration of xerostomia caused by radiation are outlined in Table 3 .

It is proved that pilocarpine medication could moderately affect xerostomia caused by radiation but the efficiency of this method on prevention xerostomia is shown to be limited. Furthermore, its extensive clinical application might be restricted because of potential of unwanted symptoms caused by medic remedies particularly, headaches, vasodilation, sweating and urinary urgency. ${ }^{36}$ Lovelace et al. ${ }^{37}$ by studying around management of radiotherapy-induced salivary hypofunction and consequent xerostomia in patients with oral or head and neck cancer showed that although cholinergic agonists like cevimeline and pilocarpine are more impressive remedies for xerostomia syndrome caused by radiation than artificial saliva substitute spray, acupuncture medicine and hyperbaric oxygen therapy are also the second remedies for decreasing subjective intensity of this syndrome.

\section{Pathophysiology of Xerostomia}

The pharynx and cavity of the mouth are rubbed with oil and protected by saliva. A healthy oral mucosa could produce about $1.5 \mathrm{~L} /$ day. This microbial secretor of the mouth replenishes teeth, prepare the initial bolus of food and also helps in lubricating the mucosa of the mouth. ${ }^{17}$ Saliva and salivary glands are main parts of the immune system of oral mucosa. Saliva have antimicrobial materials such as lactoferrin, lysozyme, oxidoreductases and antifungal peptide histatin. ${ }^{10}$ Human body have three pairs of major salivary glands: the sublingual, the submandibular and parotid glands. The parotid is a predominantly serous gland, while the sublingual and submandibular have both serous and mucous cells together. ${ }^{17}$ The three pairs of mentioned glands provide the major part of saliva in replication to an exogenous motivate. Any of the mentioned glands is contained of a well angiogenesis system of ducts and acini. Additionally, these glands are divided into lobules and lobes by linked septa of tissue which include ducts, nerves, lymphatics and vessels. As mentioned by Ortholan et al. ${ }^{17}$ secretory cells cluster like acini, configure functional tissue the saliva. They convey liquid via solute material in solvent liquid combined with sodium chloride. The acini purvey is the major part of protein to saliva. O'Sullivan and Higginson $^{38}$ have worked around oral outcomes resulting from head and neck radiotherapy and cited that, due to the position of the initial tumor and local lymph glands, the cavity of the mouth and salivary glands of patients with neck and head cancer are always in the scope of radiation.Cconsequently, changes that comes after radiation will happen in tissues which are in scope of radiation during the tumor radiotherapeutic treatment. $^{38}$

Mamais et al. ${ }^{39}$ by working on the relative susceptibility of the human parotid gland to the harmful effect of ionizing

\begin{tabular}{|c|c|c|c|}
\hline Method & Patients (n) & Author (year) & Outcomes \\
\hline $\begin{array}{l}\text { Surgically transfer of submandibular gland } \\
\text { versus control }\end{array}$ & 24 versus 11 & Rieger et al.. ${ }^{24}$ & $\begin{array}{l}\text { surgically transfer of submandibular gland was useful in } \\
\text { advancing impressive swallowing }\end{array}$ \\
\hline Surgically transfer of submandibular gland & 8 & $\begin{array}{l}\text { Al-Qahtani } \\
\text { et al. }{ }^{26}\end{array}$ & $\begin{array}{l}\text { moderate symptoms of xerostomia was seen in about } 37.5 \% \\
\text { of patients }\end{array}$ \\
\hline Surgically transfer of submandibular gland & 44 & Jha et al..$^{27}$ & $\begin{array}{l}\text { About } 75 \% \text { of patients were survived from being affecting } \\
\text { via xerostomia }\end{array}$ \\
\hline $\begin{array}{l}\text { Amifostine cytoprotective adjuvant versus } \\
\text { control }\end{array}$ & 67 & $\begin{array}{l}\text { Veerasarn } \\
\text { et al. }{ }^{28}\end{array}$ & $\begin{array}{l}\text { amifostine cytoprotective adjuvant decreased severe } \\
\text { xerostomia from } 80 \% \text { to } 40 \%\end{array}$ \\
\hline $\begin{array}{l}500 \text { mg Amifostine cytoprotective adjuvant } \\
\text { before chemotherapy }\end{array}$ & 54 & Anne et al. ${ }^{29}$ & $\begin{array}{l}\text { About half of patients had severe xerostomia and others } \\
\text { affected via xerostomia after one year }\end{array}$ \\
\hline $\begin{array}{l}\text { Amifostine cytoprotective adjuvant versus } \\
\text { control }\end{array}$ & 519 versus 332 & Buntzel et al. ${ }^{30}$ & $\begin{array}{l}\text { In those patients who remedied with amifostine the occur- } \\
\text { rence of xerostomia was more gentle during the first year of } \\
\text { treatment }\end{array}$ \\
\hline 500 mg amifostine before chemotherapy & 20 & Law et al. ${ }^{31}$ & $\begin{array}{l}\text { G2 xerostomia occurrence during first year was about } 40 \% \\
\text { and during } 1.5 \text { year was about } 30 \%\end{array}$ \\
\hline $\begin{array}{l}30-45 \text { mg of cevimeline agonist three } \\
\text { times per day }\end{array}$ & 570 & Chambers et al. ${ }^{32}$ & $\begin{array}{l}\text { cevimeline agonist could enhance unmotivated flow } \\
\text { rate of saliva }\end{array}$ \\
\hline Pilocarpine & 84 & $\begin{array}{l}\text { Almeida and } \\
\text { Kowalski }\end{array}$ & pilocarpine could cause salivary flow \\
\hline Flavourless chewing gum & 25 & Kaae et al. ${ }^{21}$ & chewing gum could cause salivary flow \\
\hline Acupuncture medicine versus control & 6 versus 6 & Cho et al. ${ }^{34}$ & $\begin{array}{l}\text { There was not any significant difference among acupuncture } \\
\text { medicine group and the control group }\end{array}$ \\
\hline Acupuncture medicine versus control & 40 versus 46 & Meng et al..$^{19}$ & $\begin{array}{l}\text { remarkable diversity among groups was discovered (in favor } \\
\text { of acupuncture medicine) }\end{array}$ \\
\hline Hypnotherapy & 12 & Schiff et al. ${ }^{3.5}$ & $\begin{array}{l}\text { the extent of saliva flow could be increased in about } 75 \% \text { of } \\
\text { patients by hypnotherapy }\end{array}$ \\
\hline $\begin{array}{l}\text { Auriculotherapy as an alternative medicine } \\
\text { versus placebo drug }\end{array}$ & 60 versus 65 & Alimi $^{23}$ & $\begin{array}{l}\text { auriculotherapy could remedy oral dryness in } 66 \% \text { of patients } \\
\text { versus } 4 \% \text { from placebo drug group }\end{array}$ \\
\hline
\end{tabular}


radiation stated that the salivary glands tissues are permanent and do not have high index of mitotic. Moreover, the salivary glands cells do not have fat rates of movement which mention that the damages of radiation therapy could not become obvious long time after the remedy. ${ }^{39}$ On this regard, it could be derived that salivary glands cells are somewhat radioresistant. However, as reported by Mamais et al. ${ }^{39}$ changes in saliva composition and quality will occur soon after irradiation that known as initial effects which stating that the gland tissue is hardly radiosensitive in approximately one functional aspect. It is while by placement of major salivary glands within scope of radiation, dysfunction of saliva predictably and instantly develops in dependent on dose of radiation. Tanasiewicz et al. ${ }^{8}$ by studying around salivary dysfunction caused via radiation reported that about $55 \%$ of salivary flow will decrease after the first week of radiation. Additionally, as a consequence the saliva viscosity will increase, denoting that some small sac like cavity of mucosa is still operable. However, at this stage most of the patients will experience the initial signs of xerostomia. Anyway, by continuing radiation therapy and increasing total dose of radiation, the function of saliva will decrease more.

The extent of dysfunction of saliva caused by radiation depends on some various factors such as dose of radiation, radiation scope, initial function of salivary gland and the volume of saliva. ${ }^{40,41}$ The radiation scope, especially the volume of gland tissue that exposed to radiation is the main determinative factor of xerostomia development and salivary dysfunction. ${ }^{42}$ Teguh et al. ${ }^{43}$ have investigated the effects of radiotherapy on human parotid saliva and reported that the major glands are mostly within the radiation scope, so intensive dysfunction could be seen among them. It is while, in patients whose location of tumor is somehow that makes the separation of major glands easier, the development of xerostomia and dysfunction of glands is less. According to their studies, almost all patients who affected via neck and head cancer receive about $60 \mathrm{~Gy}$ as a medicinal dose. However, traditional treatments are mostly specified by fractionalized radiotherapy over a 6-week period of time, once per day, 5 days per week, for a tumor remedied with a 2-Gy dose.

\section{Xerostomia Clinical Course}

Oral consequence of radiotherapy in neck and head region are the result of irradiation disadvantageous effects on mucosa of the mouth, salivary glands, dentition, bone, muscles of mastication and the two joints connecting the jawbone to the skull. The extent and the incidence of this secondary effects depends more on the total dose of radiation, ionizing irradiation type, dose fractionation and the irradiated tissue volume. Xerostomia is an intellectual complaint of mouth dryness that could be caused via dysfunction of salivary gland. The xerostomia consequences are such as discomfort and dysfunction of mouth mucosa and also in some cases speech difficulties. ${ }^{44}$ The consequences of salivary gland hypofunction also include periodontal disorder, a change in microflora in oral cavity, oral soft tissues variations and also tooth caries caused via salivary gland hypofunction. ${ }^{45}$ Additionally, Turner ${ }^{45}$ cited that some alterations of mucosa like ulceration, atrophy and inflammation are common. Variation in microbial populations of the mouth mucosa could enhance the tooth decay and also cause frequent occurrence of oral thrush. ${ }^{46}$ However, patients may experience unusual swallowing patterns, somehow the boluses movement to the throat is not smooth. Dysfunction of saliva could reduce general health besides. Symptoms of oral mucosa can change the diet and also lead patients to nutritional deficits. ${ }^{47}$ Newly, chronic inflammation of the oesophagus in patients with xerostomia caused by radiation was recognized. ${ }^{48}$ As reported by Kam et al. ${ }^{49}$ the salivary flow loss and reduced $\mathrm{PH}$ of oesophagus would contribute to expansion of gastroesophageal reflux disorder.

\section{Xerostomia Assessment via SGS Procedure}

Dugonji et al. ${ }^{50}$ have worked on diagnostic validity of dynamic salivary gland scintigraphy with ascorbic acid stimulation in patients with Sjoegren's syndrome and introduced salivary gland scintigraphy as a helpful high accurate diagnostic test for detecting syndrome of Sjögren's. Additionally, as cited by Vinagre et al. ${ }^{51}$ the imaging technique is extensively known as a useful tool for salivary gland function assessment and also diagnostic specified method for detecting initial Sjögren's syndrome. However, salivary gland scintigraphy enables the quantitative assessment of salivary glands' parenchymal function after radioiodine therapy in differentiated thyroid cancer management. It is specified by its capability in variability of intraindividual observer, also by reproducibility that makes possible the detection of variations in function of parenchyma in a little scope of $5-10 \% .^{52}$ This provides the initial detection of the syndrome of Sjögren's and impaired parenchyma of salivary glands that are caused due to radioiodine therapy. ${ }^{53} \mathrm{Con}$ sequently, salivary gland scintigraphy could be applied as an adequate imaging technique for quantitative assessment of parenchymal function of salivary gland.

As cited by Hsiung et al. ${ }^{54}$ the evaluation of the salivary glands residual function could be performed by SGS and measuring flow rate of salivary gland. The main application of SGS is to evaluate the function of salivary gland in patients who recognized to complaint from oral dryness. So, SGS is a fundamental practical method that makes possible the concurrent assessment of function and parenchyma of major salivary gland. In this method after injection of 99mTc-sodium pertechnetate, consecutive anterior projection images of head are needed during a variable period of time, generally between 20 and $40 \mathrm{~min}$. After that the images are stored and interest glandular regions in the skull are drawn by using hand. ${ }^{55}$ By using computer software, time-activity curves could be produced for any of the major salivary glands. These curves are divided into two phases, the excretion phase and the uptake phase. Excretion phase curves that are set up by using of salivary motivation administration like lemon juice, which correlates with elimination of tracer via the oral cavity, providing information on the salivary ducts patency and the system overall functional integrity. Uptake phase curves corresponding to the tracer accumulation by the glandular functional tissue and the protocol depended duration (Fig. 1).

Although, SGS procedure is widely applied for the assessment of patients with xerostomic, but is not powerfully systematized for the evaluation of such syndromes like Sjögren. ${ }^{56}$ There has been an extensive attention to SGS as a useful method in the assessment of oral mucosa dryness symptoms from decades ago. Nishiyama et al. ${ }^{14}$ have worked on a study to standardize quantitative evaluation of parotid gland scintigraphy in patients with Sjögren's syndrome and cited that although SGS method that is generally based on Schall's 


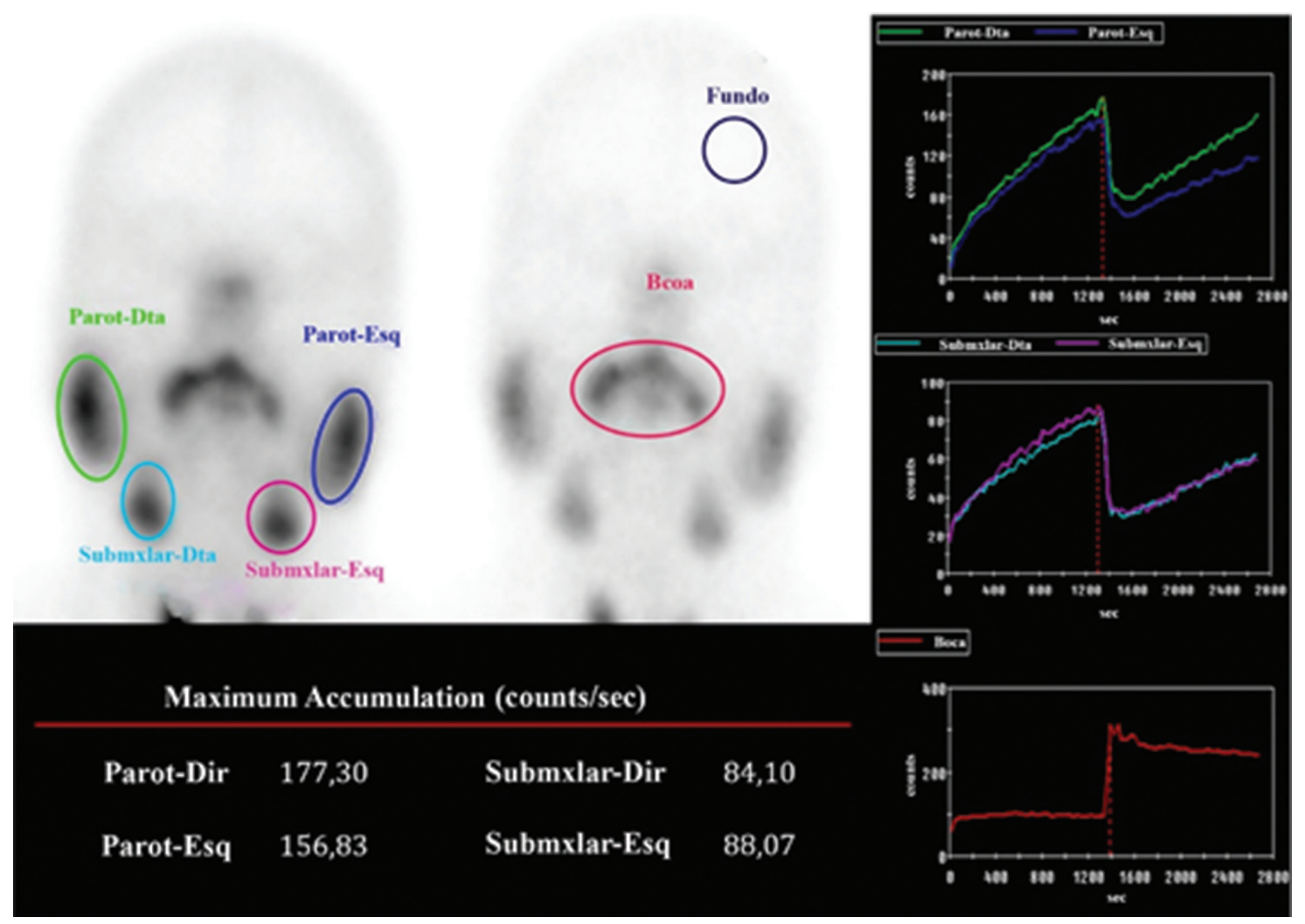

Fig. 1 An illustration of an ordinary salivary gland scintigraphy with normal tracer uptake and excretion phases and well-defined accumulation in time-activity curves. Parot-Esq (left parotid gland); Submxlar-Esq (left submandibular gland); Parot-Dta (right parotid gland); counts (tracer accumulation); Boca (mouth); sec (time in seconds); Submxlar-Dta (right submandibular gland); Fundo (background).

classification $^{57}$ is easy and simple to perform and also qualitative and depends on the observer, but its boundary related results may be classified incorrectly by the evaluator subjective judgement. Based on this classification, dysfunction of salivary gland is categorized into four grades, in according with uptake severity and mouth activity after administration of excretory motivation, the normal state is grade 1 and the whole lack of uptake mouth activity is grade 4 . This comprehensive categorization is taking into consideration as the standard method for interpretation of salivary scintigram.

In the main Schall's classification, every gland was categorized independently. For purposes of simplification, some of the authors take into account high values of both submandibular and parotids glands altogether or consider just the maximum glandular value. Shiboski et al..$^{58}$ for determining the cut-off value have used grade 3 of Schall's classification, somehow in their study by including all of the patients they reached to a general specificity and sensitivity of SGS for the assessment of SS disorder of 98\% and 54\% respectively. Ramos et al. $^{59}$ by studying the accuracy of assessment of each diagnostic test for involvement of oral cavity in patients with SS, achieved an overall specificity and sensitivity of SGS, clarified according to the Schall's classification of $80 \%$ and $87 \%$ respectively.

In order to purify the interpretation of salivary gland scintigram and enhancing diagnostic precision, there is a comprehensive attention to glandular function quantification. Various parameters have been suggested by some researchers that little agreement exists about the most trustworthy one for SS recognition and also their portion to improvement of scintigraphy accuracy. ${ }^{52,60}$

\section{Quantitative Scores Development in SGS}

The evolution of powerful gamma cameras and improvement of related software's could improve the quantitative SGS assessment, with the aim of purifying its explanation. According to Aung et al. ${ }^{53}$ and Chung et al. ${ }^{61}$ reported that quantitative SGS is delicate sufficient to discover abnormalities of only $25 \%$ destruction of gland parenchyma permitting to recognize smooth glandular dysfunction in early SS. During the last few decades, various parameters are derived according to timeactivity curves that are presented in Table 4 and are considered as accurate measures for recognition of SS. ${ }^{14,60,62,63}$ These computer-aided quantitative indicators are objective measures and numeral that easily mirror glandular function more exactly than qualitative assessment. For improving the diagnostic performance of the quantitative assessment in SS, various authors suggested an organized analysis of the parameters associated with salivary gland and oral activity. ${ }^{10,63}$

SS: Sjögren's syndrome, iSS: initial SS, sSS: secondary SS, SGS: salivary gland scintigraphy, ISC: isolated Sicca complaints, MA: maximum accumulation, UR: uptake ratio, MSGB: minor salivary gland biopsy, MS: maximum secretion, E\%: percentage of stimulated excretion, $\mathrm{C} \%$ : percentage of peak tracer distribution, PRI: prestimulatory oral index, POI: poststimulatory oral activity index, US: uptake speed, EF: excretion fraction, SV: secretion velocity, ES: excretion speed, U4 and U14: percentage of background corrected counts at 4 and $14 \mathrm{~min}$, TI: time interval among ascular perfusion peak and maximum oral activity point, Tmin: time interval among stimulation to minimum count, Tmax: time interval required to get peak uptake. 
Table 4 Various parameters of quantitative SGS derived in according to time-activity curves

\begin{tabular}{|c|c|c|c|}
\hline Methods and patients & Restrictions & Outcomes & Authorships \\
\hline \multirow{2}{*}{$\begin{array}{l}\text { Tmax, Tmin, UR, MSGB, MA, MS, } \\
\text { SV, PRI, POI, TI and Quantitative } \\
\text { SGC (Control group: 21, } \\
\text { primary SS: 29, progressive } \\
\text { SS: 41) }\end{array}$} & \multirow{2}{*}{$\begin{array}{l}\text { SS stages were categorized } \\
\text { according to the result of MSGB, } \\
\text { SS could not be reflected based } \\
\text { on classification criteria }\end{array}$} & $\begin{array}{l}\mathrm{POI}, \mathrm{TI}, \mathrm{MA} \text { and UR of the SM glands will decrease with } \\
\text { disorder progress. }\end{array}$ & \multirow[t]{2}{*}{ Aung et al. ${ }^{53}$} \\
\hline & & $\begin{array}{l}\text { The oral indicators correlation will decrease with MSGB } \\
\text { focus scores }\end{array}$ & \\
\hline \multirow{4}{*}{$\begin{array}{l}\text { Quantitative SGS, Tmax, UR, } \\
\text { MA (\%), MS (\%), PRI (\%), U14, } \\
\text { U4 (Control group: 15, SS } \\
\text { patients: 17, Autoimmune } \\
\text { disorders without SC: 18) }\end{array}$} & \multirow{2}{*}{$\begin{array}{l}\text { Group A recognized with } \\
\text { primary and secondary SS } \\
\text { patients. }\end{array}$} & Left submandibular and parotid glands URs decreased. & \multirow[t]{4}{*}{ Adams et al. ${ }^{60}$} \\
\hline & & Oral Tmax decreased in contrast with control group. & \\
\hline & \multirow{2}{*}{$\begin{array}{l}\text { Little amount of patients with } \\
\text { initial SS. }\end{array}$} & U4 decreased. & \\
\hline & & $\begin{array}{l}\text { Special involvement of SM, significant overlap of } \\
\text { quantitative indicators among groups. }\end{array}$ & \\
\hline \multirow{3}{*}{$\begin{array}{l}\text { MSGB, US, ES, EF, Saxon test, } \\
\text { Quantitative SGS peak count } \\
\text { (Autoimmune disorder without } \\
\text { SS: } 23 \text {, iSS: } 34 \text { and sSS: } 11 \text { ) }\end{array}$} & \multirow{3}{*}{$\begin{array}{l}\text { No one were incorporated as } \\
\text { control group. }\end{array}$} & ES and peak count decreased. & \multirow[t]{3}{*}{ Nishiyama et al. ${ }^{14}$} \\
\hline & & Peak count correlation decreased on MSGB. & \\
\hline & & ES decreased in Saxon trial. & \\
\hline \multirow{3}{*}{$\begin{array}{l}\text { The percentage of C, E and } \\
\text { Tmax; Quantitative SGS } \\
\text { (Control group: 8, SS: 8, ISC: 16) }\end{array}$} & \multirow{3}{*}{$\begin{array}{l}\text { Little SS patients number (8); } \\
\text { no distinction among initial and } \\
\text { secondary SS. }\end{array}$} & High Tmax in SS patients. & \multirow{3}{*}{$\begin{array}{l}\text { Henriksen and } \\
\text { Nossent }^{56}\end{array}$} \\
\hline & & Low parotid C\% in SS and ISC patients. & \\
\hline & & Low E\% in SS patients & \\
\hline
\end{tabular}

Conducted studies assessed various scintigraphic parameters and incorporated controls and inharmonious populations of patients.

The major purpose of gaining quantitative scores is the distinction of normal from abnormal results, where qualitative examination has some restrictions and becomes subjective. Anyway, Loutfi et al. ${ }^{52}$ by working around the use of semiquantitative analysis for uptake and clearance of salivary gland scintigraphy established a wide scattering of a lot of quantitative indicators. Dugonji et al. ${ }^{50}$ proved that to incorporate a broad range of normal values, the setting of cutout scopes to preserve the favorable specific condition and negative prognostic values may seriously compromise the positive prognostic values and sensitivity. Now no any clear agreement on which quantitative indicator are more suitable and reliable for assessment of SS.

The obvious discrepancy in literature about the dependability and true value of the parameters developed from the broad scattering of normality values, perhaps as a result of the studied populations incongruity, the patient's liability in various stages of the disorder and also the absence of a normal procedure of salivary scintigraphy, both in terms of attainment as in parameters that should be processed. ${ }^{62}$ So, for accepting these indicators and comprising them in explanation of SGS, a broad attempt must be constructed in both term of systematizing procedure of SGS and carrying out multicenter trials. This could allow the designation of general normality and cutout values, plus its sensitivity assessment, specificity and resultful progressive value for assessment of SS. By knowing this fact that SGS is a comprehensive diagnostic tool, it may be beneficial for remedial decision, somehow the possibly functioning glandular tissue demonstration is crucial for secretagogues application. Additionally, in follow-up stage of patient, SGS provide the assessment of remedial response and evaluation of disorder over time. ${ }^{64}$

\section{Conclusion}

Salivary gland scintigraphy is known as a reliable non-invasive procedure for assessment of function of salivary glands in patients with xerostomia symptoms. In addition, SGS is proved to be helpful in objective assessment of xerostomia as dysfunction of salivary gland that is established by international classification criteria. The accuracy of SGS method help us to discover moderate abnormalities of glandular parenchyma. On the other hand, the outcomes of SGS is associated with SS clinicopathologic characteristics, with production of nonmotivated saliva, radiosialography and focus scores in biopsy of minor salivary gland. The most frequent applicable method for clarification of salivary scintigraphy is the qualitative assessment by using of Schall's classification that is a subjective method and somehow bear form restricted capability to differentiate boundary results. The application of quantitative indicators might purify the SGS interpretation and may enhance the validity of this strategy for SS assessment, while the SGS standardization is essential for making it to be capable for daily practice. Moreover, as proved in according to the outcomes of this comprehensive research, SGS is a beneficial method for remedial decisions and also appropriate follow-up of patients.

\section{Conflicts of Interest}

None. 


\section{References}

1. Bhide SA, Miah AB, Harrington KJ, Newbold KL, Nutting CM. Radiationinduced xerostomia: pathophysiology, prevention and treatment. Clin Oncol (R Coll Radiol). 2009;21:737-744.

2. Dirix P, Nuyts S, Vander Poorten V, Delaere P, Van den Bogaert W. The influence of xerostomia after radiotherapy on quality of life: results of a questionnaire in head and neck cancer. Support Care Cancer. 2008;16:171-179.

3. Mortazavi H, Baharvand M, Movahhedian A, Mohammadi M, Khodadoustan A. Xerostomia due to systemic disease: a review of 20 conditions and mechanisms. Ann Med Health Sci Res. 2014;4:503-510.

4. Villa A, Polimeni A, Strohmenger L, Cicciù D, Gherlone E, Abati S. Dental patients'self-reports of xerostomia and associated risk factors. J Am Dent Assoc. 2011;142:811-816.

5. Napeñas JJ, Brennan MT, Fox PC. Diagnosis and treatment of xerostomia (dry mouth). Odontology 2009;97:76-83.

6. Porter SR, Fedele S, Habbab KM. Xerostomia in head and neck malignancy. Oral Oncol. 2010;46:460-463.

7. Pinna R, Campus G, Cumbo E, Mura I, Milia E. Xerostomia induced by radiotherapy: an overview of the physiopathology, clinical evidence, and management of the oral damage. Ther Clin Risk Manag. 2015;11:171-188.

8. Tanasiewicz M, Hildebrandt T, Obersztyn I. Xerostomia of various etiologies: a review of the literature. Adv Clin Exp Med. 2016;25:199-206.

9. Berk L. Systemic pilocarpine for treatment of xerostomia. Expert Opin Drug Metab Toxicol. 2008;4:1333-1340.

10. Caglar M, Tuncel M, Alpar R. Scintigraphic evaluation of salivary gland dysfunction in patients with thyroid cancer after radioiodine treatment. Clin Nucl Med. 2002;27:767-771.

11. Manthorpe R. Sjogren's syndrome criteria. Ann Rheum Dis. 2002;61: 482-484.

12. Vitali C, Bombardieri S, Jonsson R, Moutsopoulos HM, Alexander EL, Carsons SE, et al. Classification criteria for Sjogren's syndrome: a revised version of the European criteria proposed by the AmericanEuropean Consensus Group. Ann Rheum Dis. 2002;61:554-558.

13. Solans R, Bosch JA, Galofré P, Porta F, Roselló J, Selva-O'Callagan A, et al. Salivary and lacrimal gland dysfunction (Sicca syndrome) after radioiodine therapy. J Nucl Med. 2001;42:738-743.

14. Nishiyama S, Miyawaki S, Yoshinaga Y. A study to standardize quantitative evaluation of parotid gland scintigraphy in patients with Sjögren's syndrome. J Rheumatol. 2006;33:2470-2474.

15. Burlage FR, Coppes RP, Meertens H, Stokman MA, Vissink A. Parotid and submandibular/sublingual salivary flow during high dose radiotherapy. Radiother Oncol. 2001;61:271-274.

16. Murdoch-Kinch CA, Kim HM, Vineberg KA, Ship JA, Eisbruch A. Dose-effect relationships for the submandibular salivary glands and implications for their sparing by intensity modulated radiotherapy. Int J Radiat Oncol Biol Phys. 2008;72:373-382.

17. Ortholan C, Chamorey E, Benezery K, Thariat J, Dassonville O, Poissonnet $G$, et al. Modeling of salivary production recovery after radiotherapy using mixed models: determination of optimal dose constraint for IMRT planning and construction of convenient tools to predict salivary function. Int J Radiat Oncol Biol Phys. 2009;73:178-186.

18. Jensen SB, Pedersen AM, Vissink A, Andersen E, Brown CG, Davies AN, et al. A systematic review of salivary gland hypofunction and xerostomia induced by cancer therapies: management strategies and economic impact. Support Care Cancer 2010;18:1061-1079.

19. Meng Z, Garcia MK, Hu C, Chiang J, Chambers M, Rosenthal DI, et al. Randomized controlled trial of acupuncture for prevention of radiationinduced xerostomia among patients with nasopharyngeal carcinoma. Cancer. 2012:118:3337-3344.

20. Nevens D, Nuyts $S$. The role of stem cells in the prevention and treatment of radiation-induced xerostomia in patients with head and neck cancer. Cancer Med. 2016:5:1147-1153.

21. Kaae JK, Stenfeldt L, Eriksen JG. Xerostomia after radiotherapy for oral andoropharyngeal cancer: increasing salivary flow with tasteless sugarfree chewing gum. Front Oncol. 2016;6:111.

22. Spiegelberg L, Djasim UM, van Neck HW, Wolvius EB, van der Wal KG. Hyperbaric oxygen therapy in the management of radiation-induced injury in the head and neck region: a review of the literature. J Oral Maxillofac Surg. 2010;68:1732-1739.

23. Alimi D. Xerostomia induced by radiotherapy. Ther Clin Risk Manag. 2015;11:1149-1152.

24. Rieger J, Seikaly H, Jha N, Harris J, Williams D, Liu R, et al. Submandibular gland transfer for prevention of xerostomia after radiation therapy: swallowing outcomes. Arch Otolaryngol Head Neck Surg. 2005;131:140-145.
25. Zhuang L, Yang Z, Zeng X, Zhua X, Chen Z, Liu L, et al. The preventive and therapeutic effect of acupuncture for radiation-induced xerostomia in patients with head and neck cancer: a systematic review. Integr Cancer Ther. 2013;12:197-205.

26. Al-Qahtani K, Hier MP, Sultanum K, Black MJ. The role of submandibular salivary gland transfers in preventing xerostomia in the chemoradiotherapy patient. Oral Surg Oral Med Oral Pathol Oral Radiol Endod. 2006;101:753756.

27. Jha N, Harris J, Seikaly H, Jacobs JR, McEwan AJ, Robbins KT, et al. A phase II study of submandibular gland transfer prior to radiation for prevention of radiation-induced xerostomia in head-and-neck cancer (RTOG 0244). Int J Radiat Biol Phys. 2012;84:437-442.

28. Veerasarn V, Phromratanapongse P, Suntornpong N, Lorvidhaya V, Sukthomya V, Chitapanarux I, et al. Effect of amifostine to prevent radiotherapy-induced acute and late toxicity in head and neck cancer patients who had normal or mild impaired salivary gland function. J Med Assoc Thai. 2006;89:2056-2067.

29. Anné PR, Machtay M, Rosenthal DI, Brizel DM, Morrison WH, Irwin DH, et al. A Phase II trial of subcutaneous amifostine and radiation therapy in patients with head-and-neck cancer. Int J Radiat Biol Phys. 2007;67:445-452.

30. Buntzel J, Glatzel M, Mücke R, Micke O, Bruns F. Influence of amifostine on late radiation-toxicity in head and neck cancer-a follow-up study. Anticancer Res. 2007;27:1953-1956.

31. Law A, Kennedy T, Pellitteri P, Wood C, Christie D, Yumen O. Efficacy and safety of subcutaneous amifostine in minimizing radiation-induced toxicities in patients receiving combined-modality treatment for squamous cell carcinoma of the head and neck. Int J Radiat Biol Phys. 2007;69: 1361-1368.

32. Chambers MS, Posner M, Jones CU, Biel MA, Hodge KM, Vitti R, et al. Cevimeline for the treatment of postirradiation xerostomia in patients with head and neck cancer. Int J Radiat Oncol Biol Phys. 2007;68:1102-1109.

33. Almeida JP, Kowalski LP. Pilocarpine used to treat xerostomia in patients submitted to radioactive iodine therapy: a pilot study. Braz J Otorhinolarynol. 2010;76:659-662 [Article in English and Portuguese]

34. Cho JH, Chung WK, Kang W, Choi SM, Cho CK, Son CG. Manual acupuncture improved quality of life in cancer patients with radiation-induced xerostomia. J Altern Complement Med. 2008;14:523-526.

35. Schiff E, Mogilner JG, Sella E, Doweck I, Hershko O, Ben-Arye E, et al. Hypnosis for postradiation xerostomia in head and neck cancer patients: a pilot study. J Pain Symptom Manage. 2009;37:1086.e1-1092.e1.

36. Cheng CQ, Xu H, Liu L, Wang RN, Liu YT, Li J, et al. Efficacy and safety of pilocarpine for radiation-induced xerostomia in patients with head and neck cancer: a systematic review and meta-analysis. J Am Dent Assoc. 2016;147:236-243.

37. Lovelace TL, Fox NF, Sood AJ, Nguyen SA, Day TA. Management of radiotherapy-induced salivary hypofunction and consequent xerostomia in patients with oral or head and neck cancer: meta-analysis and literature review. Oral Surg Oral Med Oral Pathol Oral Radiol. 2014;117:595-607.

38. O'Sullivan EM, Higginson IJ. Clinical effectiveness and safety of acupuncture in the treatment of irradiation-induced xerostomia in patients with head and neck cancer: a systematic review. Acupunct Med. 2010;28:191-199.

39. Mamais C, Dias A, Walker J, Vydianath SR. Parotid actinomycosis mimicking metastatic lymphadenopathy. West Indian Med J. 2011;60:349-350.

40. Teymoortash A, Muller F, Juricko J, Bieker M, Mandic R, Librizzi D, et al. Botulinum toxin prevents radiotherapy-induced salivary gland damage. Oral Oncol. 2009:45:737-739

41. Aghemo A, Rumi MG, Monico S, Banderali M, Russo A, Ottaviani F, et al. Ribavirin impairs salivary gland function during combination treatment with pegylated interferon alfa-2a in hepatitis C patients. Hepat Mon. 2011;11:918-924

42. Sánchez-Pablo MA, González-García V, del Castillo-Rueda A. Study of total stimulated saliva flow and hyperpigmentation in the oral mucosa of patients diagnosed with hereditary hemochromatosis. Series of 25 cases. Med Oral Patol Oral Cir Bucal. 2012;17:e45-e49.

43. Teguh DN, Levendag PC, Noever I, et al. Early hyperbaric oxygen therapy for reducing radiotherapy side effects: Early results of a randomized trial in oropharyngeal and nasopharyngeal cancer. Int J Radiat Oncol Biol Phys. 2009;75:711-716

44. Wick JY. Xerostomia: causes and treatment. Consult Pharm. 2007;22:985-992.

45. Turner MD. Hyposalivation and xerostomia: etiology, complications, and medical management. Dent Clin N Am. 2016;60:435-443.

46. Pinheiro A, Marcenes W, Zakrzewska JM, Robinson PG. Dental and oral lesions in HIV infected patients: a study in Brazil. Int Dent J. 2004;54: $131-137$. 
47. Hammerlid E, Taft C. Health-related quality of life in long-term head and neck cancer survivors: a comparison with general population norms. $\mathrm{Br} J$ Cancer 2001;84:149-156.

48. Rosenbluth BD, Serrano V, Happersett L, Shaha AR, Tuttle RM, Narayana A, et al. Intensity-modulated radiation therapy for the treatment of nonanaplastic thyroid cancer. Int J Radiat Oncol Biol Phys. 2005;63:1419-1426.

49. Kam MK, Leung SF, Zee B, Chau RM, Suen JJ, Mo F, et al. Prospective randomized study of intensity-modulated radiotherapy on salivary gland function in early-stage nasopharyngeal carcinoma patients. J Clin Oncol. 2007; 25:4873-4879.

50. Dugonjić S1, Ajdinović B, Stefanović D, Jauković L. [Diagnostic validity of dynamic salivary gland scintigraphy with ascorbic acid stimulation in patients with Sjoegren's syndrome: comparation with unstimulated whole sialometry]. Vojnosanit Pregl. 2008;65:41-46 [Article in Serbian].

51. Vinagre F, Santos A, Santos M, Prata A, Oliveira A, Silva JC. [Salivary gland scintigraphy in the evaluation of patients with Sicca complaints]. Acta Reumatol Port 2008;33:422-428 [Article in Portuguese].

52. Loutfi I, Nair MK, Ebrahim AK. Salivary gland scintigraphy: the use of semiquantitative analysis for uptake and clearance. J Nucl Med Technol. 2003;31:81-85.

53. Aung W, Yamada I, Umehara I, Ohbayashi N, Yoshino N, Shibuya H. Sjögren's syndrome: comparison of assessments with quantitative salivary gland scintigraphy and contrast sialography. J Nucl Med. 2000;41:257-262.

54. Hsiung CY, Ting HM, Huang HY, Lee CH, Huang EY, Hsu HC. Parotid-sparing intensity-modulated radiotherapy (IMRT) for nasopharyngeal carcinoma: preserved parotid function after IMRT on quantitative salivary scintigraphy, and comparison with historical data after conventional radiotherapy. Int J Radiat Oncol Biol Phys. 2006;66:454-461.

55. Bagesund M, Richter S, Agren B, Dahllöf G. Correlation between quantitative salivary gland scintigraphy and salivary secretion rates in children and young adults treated for hematological, malignant and metabolic diseases. Dentomaxillofac Radiol. 2000;29:264-271.

56. Henriksen AM, Nossent HC. Quantitative salivary gland scintigraphy can distinguish patients with primary Sjögren's syndrome during the evaluation of Sicca symptoms. Clin Rheumatol. 2007;26:1837-1841.

57. Schall GL, Anderson LG, Wolf RO, Herdt JR, Tarpley TM Jr, Cummings NA, et al. Xerostomia in Sjögren's syndrome: evaluation by sequential scintigraphy. JAMA 1971;216:2109-2116.

58. Shiboski CH, Shiboski SC, Seror R, Criswell LA, Labetoulle M, Lietman TM, et al. 2016 American College of Rheumatology/European League Against Rheumatism classification criteria for primary Sjögren's syndrome: A consensus and data-driven methodology involving three international patient cohorts. Ann Rheum Dis. 2017;76:9-16.

59. Ramos-Casals M, Tzioufas AG, Font J. Primary Sjögren's syndrome: new clinical and therapeutic concepts. Ann Rheum Dis. 2005;64:347-354.

60. Adams BK, Al Attia HM, Parkar S. Salivary gland scintigraphy in Sjögren's syndrome: are quantitative indices the answer? Nucl Med Commun. 2003;24:1011-1016.

61. Chung MK, Kim DH, Ahn YC, Choi JY, Kim EH, Son Yl. Randomized trial of vitamin C/E complex for prevention of radiation-induced xerostomia in patients with head and neck cancer. Otolaryngol Head Neck Surg. 2016;155:423-430.

62. Demangeat R, Didon-Poncelet A, Cherfan J, Demangeat JL. Stimulated salivary pertechnetate clearance revised: correlation with dynamic scintigraphic indices in Sicca syndrome. Clin Nucl Med. 2000;25:888-894.

63. Aung W, Murata Y, Ishida R, Takahashi Y, Okada N, Shibuya H. Study of quantitative oral radioactivity in salivary gland scintigraphy and determination of the clinical stage of Sjögren's syndrome. J Nucl Med. 2001;42:38-43.

64. Hermann GA, Vivino FB. Abnormal scintigraphic patterns of uptake and secretion in Sjögren's syndrome. Arthritis Rheum. 2000:43:S306.

This work is licensed under a Creative Commons Attribution-NonCommercial 3.0 Unported License which allows users to read, copy, distribute and make derivative works for non-commercial purposes from the material, as long as the author of the original work is cited properly. 